Щербакова Олена кандидат психологічних наук, старший науковий співробітник, ДУ «Інститут охорони здоров’я дітей та підлітків НАМН України» ORCID iD: 0000-0002-9169-5471

DOI https://doi.org/10.35619/prap_rv.vi13.143

\title{
ЕМОЦІЙНИЙ ІНТЕЛЕКТ ТА АКАДЕМІЧНІ ЗДІБНОСТІ УЧНІВ СТАРШОГО ПІДЛІТКОВОГО ВІКУ
}

Анотація. Стаття присвячена виявленню особливостей емоиійного інтелекту в учнів з різними типами академічних здібностей. Доведено, щчо на рівень розвитку емпатії та здатності до управління емочіями інших позитивно позначається домінування внутрішньої мотивації у структурі типологічних профілів академічно успішних школярів. Встановлено, що нижча емочійна обізнаність, низька здатність до мотивування себе на переживання певних емоцій, слабо виражена емпатія та низька здатність до управління емочіями інших характеризують учнів з низьким рівнем академічних здібностей.

Ключові слова: академічно здібні учні, емпатія, емочійний інтелект, старший підлітковий вік, обдарованість, інтелект, креативність, мотивація.

Постановка проблеми. Наукова і соціальна значущість дослідження визначається проблемою створення спеціальної системи освіти для обдарованих дітей і молоді в Україні. У межах Всеукраїнського комплексного педагогічного експерименту «Створення системи супроводження навчання, виховання та розвитку академічно обдарованих дітей дошкільного та молодшого шкільного віку» здійснюється науково-педагогічний проект «Інтелект України» (Щербакова, 2015). Проект «Інтелект України» спрямований на створення системи виховання та освіти інтелектуальної еліти нації в контексті концепції меритократичної освіти. Проект грунтується на принципах системного, діяльнісного, синергетичного, особистісно орієнтованого, компетентнісного підходів, які узгоджуються із загально педагогічними принципами i відображають сучасний рівень і тенденції розвитку національної системи освіти.

Відповідно до концепції меритократичної освіти, за для забезпечення могутності та процвітання держави, невід'ємним є розвиток та виховання інтелектуальної еліти нації. Автор концепції - Веблен - вважав, що тільки інтелектуальна еліта спроможна ініціювати системні позитивні зрушення в суспільно-економічному та духовному розвитку суспільства(Mannheim \&Stuart, 1997). Виходячи з цього прийшло розуміння необхідності цілеспрямованого «вирощування» та зміцнення інтелектуального потенціалу нації. Цього можливо досягти тільки при своєчасному виявленні академічно обдарованих та здібних учнів й створенню для них спеціальної системи освіти. Складовими «формули успіху» у вихованні академічно здібних та обдарованих учнів є: примат розуму й здібностей над походженням, майновим і соціальним станом; створення системи пошуку та відбору академічно здібних та обдарованих учнів, створення мережі спеціальних класів для їх навчання і виховання; створення системи підготовки і перепідготовки фахівців; належне фінансування за рахунок як бюджетних, так і позабюджетних джерел.

Отже, проблема навчання й виховання академічно здібних дітей і молоді набула особливого значення, психодіагностика дитячих здібностей i обдарованості має розв'язуватися на двох рівнях - теоретичному та психометричному. На теоретичному рівні було передбачено створення концепції здібностей і обдарованості, основні положення якої мають бути вихідними для розробки психодіагностичних процедур і методики проведення 
досліджень, спрямованих на виявлення здібних та обдарованих дітей і молоді. На психометричному рівні було заплановано створення блоку діагностичного інструментарію, який би дозволив відповідно до розробленої концепції ідентифікувати здібних та обдарованих учнів основної школи(Юркевич, 1990; Cline \& Schwartz, 1990; Lovecky, 1999).

Питання виявлення академічно здібних і обдарованих дітей на сьогодні пов'язуються iз питанням розробки концептуальних моделей обдарованості та здібностей. До числа найпопулярніших у сучасній світовій педагогіці теоретичних моделей обдарованості належить модель, розроблена відомим американським психологом Рензуллі (Renzulli, 1986), у якій обдарованість являє собою інтегративну якість особистості, структурними компонентами якої є здібності, що перевищують середній рівень, креативність і мотивація. Відповідно до своєї концепції, Дж. Рензуллі наголошував на тому, що контингент обдарованих дітей може бути значно ширшим, ніж під час їх ідентифікації за тестами інтелекту та тестами креативності. Тому науковець пропонує відносити до категорії обдарованих та здібних усіх дітей, які виявили високі показники хоча б за одним із компонентів його моделі. Короткочасним дослідженням 3 ідентифікації дитячої обдарованості притаманні певні недоліки, тому за для їх подолання Дж. Рензуллі почав застосовувати довготривалі психолого-педагогічні моделі діагностики, побудовані по принципу «турнікету». У межах цієї моделі процес ідентифікації обдарованих дітей являє собою лонгітюдне дослідження, яке передбачає тривале спостереження за дитиною.

Зауважимо, що при виявленні здібних та обдарованих дітей ми завжди стикаємося 3 проблемою етичного характеру. Ідентифікуючи дитину як здібну або не здібну ми можемо штучно вплинути на іiі суб'єктивні очікування. Багато життєвих конфліктів «здібних» i «нездібних» людей криються в неадекватності й легковажності вихідного прогнозу їх майбутніх досягнень. Слушним у цьому контексті виявляється також те, що дитячі здібності або обдарованість ще не є гарантом високих творчих досягнень дорослої людини і що далеко не кожний геніальний дорослий ідентифікувався педагогами як здібна дитина (Михальчук, 2010). Крім того, в контексті обдарованості доцільним виявляється також розгляд зв'язку емоційного інтелекту із академічними здібностями, втім дана проблема $\epsilon$ мало досліджуваною у сучасній педагогічній психології.

Формулювання цілей статті. Отже, метою дослідження було виявлення особливостей емоційного інтелекту в учнів з різними типами академічних здібностей.

Виклад основного матеріалу дослідження. У дослідженні застосовано тест для оцінки вербального, невербального (просторового) та математичного інтелекту Амтхауера для учнів 7-9 класів, невербальний субтест методики Торренса, оригінальна адаптована методика психодіагностики академічної саморегуляції Десі і Райана для учнів основної школи, а також опитувальник емоційного інтелекту Холла.

Усього у дослідженні взяли участь 331 учень 7-9 класів (204 учня навчаються за проектом «Інтелект Україна», 127 - учні навчаються за гімназійною програмою), 3 них 189 академічно успішних учнів та 142 академічно неуспішних учня, віком 11-15 років.

Виклад основного матеріалу. Кластеризація даних методом К-середніх за психодіагностичними методиками, які вимірюють інтелект, креативність та мотивацію, а також враховуючи середній семестровий бал, що відображає загальну (за усіма предметами загалом) та парціальну (найвищий середній бал за однією з дисциплін) успішність, окремо по вибірці академічно успішних та академічно неуспішних було отримано відповідно 5 та 3 типологічних профілі. Характеристика типологічних профілів академічно успішних учнів представлена такими кластерами.

Кластер 1 утворений високими показниками вербального, математичного та просторового інтелекту, креативності за параметром оригінальності, внутрішньої мотивації, помірними показники зовнішньої мотивації та високими показниками загальної та парціальної академічної успішності. Кластер та група учнів за ним були названі «Інтелектуально обдаровані, креативні, внутрішньо вмотивовані академічно успішні школярі». Високі результати у навчанні, особливо по окремим дисциплінам, досягаються за рахунок високого інтелекту, непересічної креативності, пізнавального інтересу, що має 
вибірковий характер. Зазначена група учнів основної школи представлена успішними учнями, більшість 3 яких на тлі достатньо високої успішності за усіма дисциплінами по окремих предметах демонструє виключно високі результати. Групу за даним профілем скали 24 особи, що становить 12,6\% вибірки академічно успішних школярів.

Кластер 2 утворений вищими за середні показниками вербального, просторового та математичного інтелекту, креативності за параметром оригінальності, низькими показниками внутрішньої мотивації, середніми показниками зовнішньої мотивації, помірно високими показниками загальної академічної успішності i високими показниками парціальної академічної успішності. Кластер і група учнів були названі «Інтелектуально обдаровані, креативні, невмотивовані академічно успішні школярі». Навчальна успішність за окремими предметами досягається за рахунок високого рівня інтелектуального і особистіснотворчого розвитку, домінуванням невербального інтелекту над вербальним. Нестаток вмотивованості на навчання, нудьгу на уроках та під час виконання домашніх завдань компенсує високий розумовий розвиток дітей, що забезпечує високу успішність за окремими навчальними дисциплінами. Іншими словами, учні цього профілю навчаються добре за тими предметами, оволодіння якими є можливим за рахунок розвитку інтелекту, зокрема у даному випадку для більшості учнів цього профілю просторовий інтелект відіграє ключову роль в парціальній успішності. Групу досліджуваних за даним профілем склали 39 осіб, що становить 20,6\% вибірки академічно успішних школярів.

Кластер 3 утворений вищими за середні показниками вербального, математичного та просторового інтелекту, низькими показниками креативності за параметром оригінальності, низькими показниками внутрішньої мотивації, високими показниками зовнішньої мотивації, помірно високими показниками загальної та парціальної академічної успішності. Кластер і відповідна група названі «Інтелектуально обдаровані, зовнішньо вмотивовані академічно успішні школярі». Навчальна успішність регулюється виключно зовнішньою мотивацією, яка компенсує нестаток креативності та інтересу до навчання учня. Учні цього профілю керуються вимоги дорослих у регуляції навчальної діяльності, виявляють менший рівень творчих здібностей. Групу досліджуваних за даним профілем склали 38 осіб, що становить 20,1\% вибірки академічно успішних школярів.

Кластер 4 утворений високими показниками вербального, математичного та просторового інтелекту, низькими показниками креативності за параметром оригінальності, високими показниками внутрішньої мотивації, низькими показниками зовнішньої мотивації - «Інтелектуально обдаровані, внутрішньо вмотивовані академічно успішні школярі». Високі навчальні результати за окремими дисциплінами забезпечуються високим рівнем розвитку інтелекту на тлі недостатньої креативності та високого пізнавального інтересу до навчання. Групу досліджуваних за даним профілем склали 52 особи, що становить 27,5\% вибірки академічно успішних школярів.

Кластер 5 утворений вищими за середні показниками вербального, математичного та просторового інтелекту, середніми показниками креативності за параметром оригінальності, низькими показниками внутрішньої мотивації, високими показниками зовнішньої мотивації, помірно високою загальною та парціальною академічною успішністю. Кластер і група «Інтелектуально обдаровані, креативні, зовнішньо вмотивовані академічно успішні школярі». Навчальна успішність забезпечується високою зовнішньою мотивацією, яка компенсує нестаток інтересу до навчання. У даному типологічному профілі вимоги дорослих виступають як регулятор навчальної діяльності школяра 3 достатнім рівнем когнітивної обдарованості. Групу досліджуваних за даним профілем склали 36 осіб, що становить 19\% вибірки академічно успішних школярів.

Характеристика типологічних профілів академічних здібностей неуспішних школярів складається з таких кластерів.

Кластер 1 утворений помірно високими показниками вербального, математичного та просторового інтелекту, середніми показниками креативності за параметром оригінальності, низькими показниками внутрішньої мотивації, низькими показниками зовнішньої мотивації, низькими показниками загальної академічної успішності, помірно високими показниками 
парціальної академічної успішності «Інтелектуально обдаровані немотивовані академічно неуспішні школярі» - назва типологічного профілю. Низькі результати у навчанні за виключенням успіхів за окремими дисциплінами обумовлені нестатком інтересу до навчання та зовнішньої мотивації. Парціальна успішність досягаються за рахунок достатньо високого інтелекту. Групу досліджуваних за даним профілем склали 31 особа, що становить 21,8\% вибірки академічно неуспішних школярів.

Кластер 2 утворений середніми та нижчими за середні показниками вербального, просторового та математичного інтелекту, низькими показниками креативності за параметром оригінальності, внутрішньої і зовнішньої мотивації, загальної та парціальної академічної успішності - «Недостатньо інтелектуально здібні, немотивовані академічно неуспішні школярі». Низька навчальна успішність обумовлена нижчим за середній рівнем когнітивного розвитку на тлі нестатку мотивації до навчання. Групу досліджуваних за даним профілем склали 54 особи, що становить 38\% вибірки академічно успішних школярів.

Кластер 3 утворений середніми та нижчими за середні показниками вербального, просторового та математичного інтелекту та креативності за параметром оригінальності, високими показниками внутрішньої мотивації, низькими показниками зовнішньої мотивації і загальної академічної успішності, помірно високими і середніми показниками парціальної академічної успішності - «Недостатньо інтелектуально здібні, внутрішньо вмотивовані академічно неуспішні школярі». Навчальна успішність досягається лише по окремим навчальний дисциплінам і обумовлена інтересом до навчання. Групу досліджуваних за даним профілем склали 57 осіб, що становить 40,2\% вибірки академічно успішних школярів.

Групи за типами академічних здібностей серед учнів 7-9 класів розподілені нерівномірно $(\chi 2$ Емп $=23,486, p<0,01)$.

Розглянемо результати порівняння показників емоційного інтелекту учнів в залежності від профілю академічних здібностей (табл. 1).

Таблиияя 1

Показники емоційного інтелекту академічно успішних учнів з різними кластерними профілями академічних здібностей

\begin{tabular}{|l|l|l|l|l|l|l|}
\hline \multirow{2}{*}{$\begin{array}{c}\text { Показники } \\
\text { емоційного } \\
\text { інтелекту }\end{array}$} & \multicolumn{5}{|c|}{ Групи за кластерами академічних здібностей академічно } & \multirow{2}{*}{ Н } \\
\cline { 2 - 7 } & 1 & 2 & 3 & 4 & 5 \\
\hline $\begin{array}{l}\text { Емоційна } \\
\text { обізнаність }\end{array}$ & $27,71 \pm 4,38$ & $24,05 \pm 6,10$ & $24,95 \pm 5,33$ & $25,58 \pm 5,42$ & $26,61 \pm 4,81$ & 7,24 \\
\hline $\begin{array}{l}\text { Емоційна } \\
\text { Саморегуляція }\end{array}$ & $24,46 \pm 4,93$ & $21,67 \pm 6,11$ & $23,37 \pm 6,01$ & $23,81 \pm 5,98$ & $23,36 \pm 6,62$ & 3,92 \\
\hline Самомотивація & $28,00 \pm 5,02$ & $26,67 \pm 5,93$ & $27,08 \pm 4,97$ & $27,67 \pm 5,52$ & $27,92 \pm 4,53$ & 1,13 \\
\hline Емпатія & $29,13 \pm 4,79$ & $25,41 \pm 6,89$ & $25,68 \pm 5,30$ & $26,23 \pm 5,87$ & $29,08 \pm 4,85$ & $12,46 *$ \\
\hline $\begin{array}{l}\text { Управління } \\
\text { емоціями } \\
\text { інших }\end{array}$ & $28,00 \pm 5,38$ & $22,97 \pm 6,69$ & $24,42 \pm 6,50$ & $26,75 \pm 5,64$ & $28,58 \pm 5,54$ & $18,95 * *$ \\
\hline
\end{tabular}

$\mathrm{p}<0,05, \mathrm{p}<0,01$

Статистично значущих відмінностей у показниках емоційної обізнаності, самомотивації та саморегуляції у школярів з високою академічною успішністю встановлено не було. За показниками емпатії «Інтелектуально обдаровані, креативні, внутрішньо вмотивовані академічно успішні школярі» та «нтелектуально обдаровані, внутрішньо мотивовані академічно успішні школярі» значно перевершують учнів інших профілів, а «Інтелектуально обдаровані, креативні, невмотивовані академічно успішні школярі» та «Інтелектуально обдаровані, зовнішньо вмотивовані академічно успішні школярі» поступаються іншим школярам за рівнем емпатії.

«Інтелектуально обдаровані, креативні, внутрішньо вмотивовані академічно успішні школярі» та «Інтелектуально обдаровані, внутрішньо мотивовані академічно успішні школярі» мають найвищі показники здатності до управління емоціями інших, a 
«Інтелектуально обдаровані, креативні, невмотивовані академічно успішні школярі» найнижчі показники такої емоційно-інтелектуальної здатності. Примітним $\epsilon$ те, що виражена емпатія та розвинута здатність до управління емоціями інших людей характеризує успішних у навчанні учнів 3 високою мотивацією до навчання, а низькі емоційно-інтелектуальні здатності - невмотивованих учнів.

У таблиці 2 показано відмінності у показниках емоційного інтелекту учнів 3 низькою успішністю у навчанні в залежності від їх профілю академічних здібностей.

Таблиия 2

\section{Показники емоційного інтелекту академічно неуспішних учнів 3 різними} кластерними профілями академічних здібностей

\begin{tabular}{|c|c|c|c|c|}
\hline \multirow{2}{*}{$\begin{array}{c}\text { Показники } \\
\text { емоційного } \\
\text { інтелекту }\end{array}$} & \multicolumn{3}{|c|}{$\begin{array}{c}\text { Групи за кластерами академічних здібностей } \\
\text { академічно неуспішних школярів }\end{array}$} & \multirow[t]{2}{*}{$\mathrm{H}$} \\
\hline & 1 & 2 & 3 & \\
\hline $\begin{array}{l}\text { Емоційна } \\
\text { обізнаність }\end{array}$ & $26,71 \pm 7,04$ & $22,63 \pm 7,04$ & $27,58 \pm 3,89$ & $16,59 * *$ \\
\hline $\begin{array}{l}\text { Емоційна } \\
\text { Саморегуляція }\end{array}$ & $23,23 \pm \pm 4,93$ & $23,48 \pm 4,93$ & $22,88 \pm 6,32$ & 0,82 \\
\hline Самомотивація & $27,68 \pm 4,07$ & $26,44 \pm 4,07$ & $28,32 \pm 5,59$ & $7,68 *$ \\
\hline Емпатія & $27,71 \pm 4,94$ & $26,61 \pm 4,97$ & $29,60 \pm 3,97$ & $12,06 * *$ \\
\hline $\begin{array}{l}\text { Управління } \\
\text { емоціями інших }\end{array}$ & $27,00 \pm 4,93$ & $24,93 \pm 5,43$ & $27,70 \pm 4,34$ & $7,62 *$ \\
\hline
\end{tabular}

$$
\mathrm{p}<0,05, \mathrm{p}<0,01
$$

Нижча емоційна обізнаність, низька здатність до мотивування себе на переживання певних емоцій, слабо виражена емпатія та низька здатність до управління емоціями інших характеризують «Недостатньо інтелектуально здібних, немотивованих академічно неуспішних школярів». Отже, низькі академічні здібності цілком відповідають низькому рівню емоційного інтелекту у старшому підлітковому віці.

Висновки та перспективи подальших досліджень. Рівень емоційного інтелекту у старшому підлітковому віці загалом відповідає рівню загального інтелекту та академічних здібностей. На рівень розвитку емпатії та здатності до управління емоціями інших позитивно позначається домінування внутрішньої мотивації у структурі типологічних профілів академічно успішних школярів. У показниках емоційної обізнаності, самомотивації та саморегуляції у школярів 3 високою академічною успішністю статистично значущих відмінностей встановлено не було. Зниження академічних здібностей за усіма параметрами загалом негативно взаємообумовлено з рівнем емоційного інтелекту.

\section{СПИСОК ПОСИЛАНЬ}

Михальчук, Н. О., Івашкевич Е. 3., Поташнюк Р. 3. (2010). Розвиток інтелектуальних можливостей школярів засобами літератури. Рівне: Принт Хауз.

Щербакова, О. О. (2015). Психологічні особливості адаптації академічно здібних дітей до навчання у початковій школі. (Дис. канд. психол. наук). Харківський національний педагогічний університет ім. Г. С. Сковороди. Харків.

Юркевич, В. С., Чудновский В. Э. (1990). Одаренность: дар или испытание. Москва.

Cline, S., \& Schwartz, D. (1999). Diverse populations of gifted children: Meeting their needs in the regular classroom and beyond. Upper Saddle River, NJ: Prentice-Hall.

Lovecky, D. V. (1999). "Gifted Children with AD/HD". Providence, RI: Gifted Resource center of New England.

Mannheim, K., \& Stuart, W.(1997). An introduction to the sociology of education. L; Mannheim K. Ideology and Utopia L., N.Y., 1936. Thorstein Veblen. The Higher Learning In America: A Memorandum On the Conduct of Universities By Business Men. 1918. 


\title{
REFERENCES
}

Mykhalchuk, N. O., Ivashkevych E. Z., \& Potashniuk R. Z. (2010). Rozvytok intelektualnykh mozhlyvostei shkoliariv zasobamy literatury [Development of intellectual abilities of students by means of literature]. Rivne: Prynt Khauz. [in Ukrainian].

Shcherbakova, O. O. (2015). Psykholohichni osoblyvosti adaptatsii akademichno zdibnykh ditei do navchannia u pochatkovii shkoli [Psychological features of adaptation academically able children to primary school]. (Dys. kand. psykhol. nauk). Kharkiv National Pedagogical University G. S. Skovoroda. Kharkiv. [in Ukrainian].

Iurkevych, V. S., \& Chudnovskyi V. E. (1990). Odarennost: dar yly yspitanye [Genius: gift or test]. Moskva. [in Russian].

Cline, S., \& Schwartz, D. (1999). Diverse populations of gifted children: Meeting their needs in the regular classroom and beyond. Upper Saddle River, N J: Prentice-Hall. [in English].

Lovecky, D. V. (1999). "Gifted Children with AD/HD". Providence, RI: Gifted Resource center of New England. [in English].

Mannheim, K., \& Stuart, W. (1997) An introduction to the sociology of education. L; Mannheim K. Ideology and Utopia L., N.Y., 1936. Thorstein Veblen. The Higher Learning In America: A Memorandum On the Conduct of Universities By Business Men. 1918. [in English].

\section{EMOTIONAL INTELLIGENCE AND ACADEMIC ABILITIES OF OLDER TEENAGE STUDENTS}

\author{
Olena Shcherbakova \\ $\mathrm{PhD}$ in Psychological Sciences, \\ Senior Researcher, \\ State Institution «Institute for Children and \\ Adolescents Health Care of the National \\ Academy of Medical Sciences of Ukraine», Kharkiv \\ ORCID iD: 0000-0002-9169-5471 \\ DOI https://doi.org/10.35619/prap_rv.vi13.143
}

\begin{abstract}
The article is devoted to revealing the emotional intelligence peculiarities of students with different types of academic abilities. As a result of clustering data on psychodiagnostic techniques that measure intelligence, creativity, and motivation, as well as considering an average semester score reflecting overall and partial academic performance, five and three typological profiles were obtained from a sample of academically successful and academically unsuccessful students.

There were no statistically significant differences found in indicators of emotional awareness, self-motivation, and self-regulation among students with high level of academic performance. It is proved that the dominance of inner motivation in the structure of typological profiles of academically successful students is positively influences the level of development of empathy and ability to manage the emotions of others. It was revealed that lower emotional awareness, low ability to motivate oneself to experience certain emotions, poorly expressed empathy and low ability to manage the emotions of others characterize students with low academic ability. It is stated that the decline in academic ability in all areas is generally negatively correlated with the level of emotional intelligence.
\end{abstract}

Key words: academically capable students, empathy, emotional intelligence, older adolescence, giftedness, intelligence, creativity, motivation.

Стаття надійшла до редакиії 19.10.2019 р. 